\title{
Protective effects of estradiol on TRAIL-induced apoptosis in a human oligodendrocytic cell line: evidence for multiple sites of interactions
}

\author{
G Cantarella ${ }^{1}$, N Risuglia ${ }^{1}$, G Lombardo ${ }^{1}$, L Lempereur ${ }^{1}$, \\ F Nicoletti ${ }^{2}, M^{2}$ Memo $^{3}$ and $R$ Bernardini ${ }^{*, 1,4}$ \\ ${ }^{1}$ Department of Experimental and Clinical Pharmacology, University of Catania, \\ Italy \\ 2 Department of Biomedical Sciences, University of Catania, Italy \\ ${ }^{3}$ Department of Biomedical Sciences and Biotechnologies, University of \\ Brescia, Italy \\ ${ }^{4}$ Etna Biotech Research Center, Catania, Italy \\ * Corresponding author: R Bernardini, Dipartimento di Farmacologia Sper- \\ imentale e Clinica, Università di Catania,Viale A Doria 6, Catania 95125, Italy. \\ Tel: + 39-095-738-4090/4240/4248; Fax: + 39-095-738-4229; \\ E-mail: bernardi@unict.it
}

Received 25.6.03; revised 29.10.03; accepted 03.11.03; published online 23.01.04 Edited by RA Knight

\begin{abstract}
Demyelinating diseases are high impact neurological disorders. Steroids are regarded as protective molecules in the susceptibility to these diseases. Here, we studied the interactions between tumour necrosis factor-related apoptosis-inducing ligand (TRAIL), a potent proapoptotic molecule toxic to oligodendrocytes, and 17- $\beta$-estradiol (E-17- $\beta)$, in human oligodendrocytic MO3.13 cells. Exposure of cells to TRAIL resulted in the upregulation of both death receptors DR4 and DR5 and apoptosis, as well as the activation of caspase-8 and -3 , increased phosphorylation of Jun- $\mathrm{N}$ terminal kinase and p38 kinase, and the reduction of bcl-2 and bcl-xL proteins. TRAIL-mediated MO3.13 cell apoptosis was abrogated by the dominant-negative form of the adaptor protein FADD and by caspase inhibitors. Preincubation with E-17- $\beta$ completely prevented both TRAIL-induced DR4 and DR5 upregulation and apoptosis. Estrogen-induced cytoprotection was time and concentration dependent and reverted by antiestrogens. Estrogen treatment per se reduced kinase phosphorylation, and upregulated bcl-2 and bcl-xL proteins. In conclusion, our data show that the detrimental role of TRAIL on oligodendrocytes can be effectively counteracted by estrogens, thus suggesting that the underlying molecular interactions can be of potential relevance in characterizing novel targets for therapy of demyelinating disorders.

Cell Death and Differentiation (2004) 11, 503-511.

doi:10.1038/sj.cdd. 4401367

Published online 23 January 2004
\end{abstract}

Keywords: protection; estradiol; oligodendroglia; demyelinating diseases; proapoptotic cytokines

Abbreviations: CNS, central nervous system; E-17- $\beta, 17-\beta$ estradiol; ER, estrogen receptor; FADD, Fas-associated death domain; JNK1, Jun-N-terminal kinase; MS, multiple sclerosis; TNF, tumour necrosis factor; TRAIL, tumour necrosis factorrelated apoptosis-inducing ligand

\section{Introduction}

Demyelinating diseases affect a wide percent of population today. Thus, unraveling the mechanisms related to these diseases as well as the role of potential protective agents have become priority tasks.

It is a commonly accepted notion that immunoinflammatory phenomena are involved in the pathogenesis of demyelinating diseases, including multiple sclerosis (MS). ${ }^{1} \mathrm{~A}$ crucial role in the initial event of MS has been attributed to oligodendroglia, a cell type actively contributing to myelin formation. ${ }^{2}$ Accordingly, although the precise mechanism(s) underlying oligodendrocyte death during MS poussées has not yet been elucidated, the loss of these cells is one of the major factors for progression of the disease. ${ }^{3,4}$

Interestingly, proinflammatory/proapoptotic cytokines, particularly those belonging to the tumour necrosis factor (TNF) superfamily, have been suggested to be, at least in part, responsible for increased cell death rate in the central nervous system (CNS), involving both the neuronal ${ }^{5}$ and the glial ${ }^{6}$ component. In this line, recent observations suggest that the tumour necrosis factor-related apoptosis-inducing ligand (TRAIL) could play a role in the pathogenesis of MS, as its increased activity is associated with detrimental effects on oligodendrocytes. ${ }^{7,8}$

TRAIL is a recently characterized member of the TNF superfamily that binds to five specific membrane receptors. ${ }^{9,10}$ Among these, receptors DR4 and DR5 are type I membrane proteins and belong to the TNF/NGF receptors superfamily. ${ }^{9,11,12}$ DR4 and DR5 also contain a death domain in their cytoplasmic region and are able to transduce a TRAILinduced death signal..$^{9,10}$ The DcRI, a glycophospholipidanchored cell surface protein, and DcRII, a receptor containing a truncated death domain, are decoy receptors that block TRAIL-induced apoptosis. ${ }^{11-13} \mathrm{~A}$ fifth TRAIL receptor, osteoprotegerin, has been characterized as a mediator of bone remodeling effects of the cytokine. ${ }^{14,15}$ Both DR4 and DR5 are distributed in the CNS of animal species and human, ${ }^{16}$ and mediate detrimental effects of TRAIL in brain ischemia ${ }^{17}$ and in $\beta$-amyloid-dependent neurotoxicity. ${ }^{18}$ Upon binding to DR4 and DR5, TRAIL activates the caspase- 8 and, eventually, the Jun-N-terminal kinase (JNK)/p38 pathway through the mitogen-activated protein kinase cascade. ${ }^{19,20}$

The observation that hormonal factors may influence susceptibility to MS has drawn attention on the possible protective effects of estrogens, ${ }^{21}$ whose receptors are expressed in different glial cells. ${ }^{22}$ For example, the severity of clinical symptoms of MS is significantly diminished during 
late pregnancy, ${ }^{23}$ when estrogen levels are significantly high. Such gender dimorphism in MS appears similar in animals with experimental autoimmune encephalomyelitis (EAE), a useful animal model for MS. ${ }^{24,25}$

Interestingly, it has been reported that estradiol interferes with the caspase activation ${ }^{26}$ and with different molecular events mediating TRAIL-induced cell death, such as the phosphorylation of the effector molecules JNK1 and p38 kinase. ${ }^{27}$ In support of these data, others have shown that estradiol is able to prevent TRAIL-induced HeLA cell death through the prevention of reactive oxygen species production and inhibition of the p38 kinase. ${ }^{27}$

Matysiak et $a .^{28}$ recently showed that human primary oligodendrocytes from human brain surgery ex vivo expressed TRAIL receptors and their exposure to TRAIL in vitro eventually resulted in cell death.

Such reports on the destructive role of TRAIL in the brain, as well as of the protective effect of estrogens, prompted us to study molecular events governing TRAIL-induced oligodendrocyte death and the possible interference of estrogens with such mechanisms.

To accomplish this task, we first investigated the expression of TRAIL and estradiol receptors in the human oligodendrocytic cell line MO3.13, a cellular hybrid of adult human oligodendrocyte and rhabdomyosarcoma cells, which expresses some properties of both oligodendrocytes and astrocytes. $^{29}$ Subsequently, we assessed the reciprocal effects of TRAIL and 17- $\beta$-estradiol (E-17- $\beta$ ) on these cells. We found that estrogens protect oligodendrocytes against TRAIL-induced apoptosis acting at different levels of the intracellular TRAIL death pathway.

\section{Results}

\section{TRAIL receptors are expressed by human oligodendrocytic cells and mediate TRAIL-induced apoptosis}

As TRAIL represents a substantial cause of oligodendrocyte death, ${ }^{28}$ in order to confirm specificity of such effect, we first studied whether the MO3.13 cell line expressed the two TRAIL receptors DR4 and DR5. In line with previous data, ${ }^{28}$ Reverse transcriptase-PCR (RT-PCR) analysis for mRNAs and Western blot analysis for proteins showed that $\mathrm{MO} 3.13$ cells express both DR4 and DR5 receptors (Figure 1a and b). In the experiments, HeLa cell samples were used as internal positive controls. $^{28}$

In further experiments, we evaluated the cytotoxic effect of TRAIL by adding $100 \mathrm{ng} / \mathrm{ml}$ of the cytokine to MO3.13 cell cultures. This concentration of TRAIL is known to induce cell death in most in vitro systems. ${ }^{10,18}$ As shown in Figure $2 \mathrm{a}$, TRAIL induced death of cultured MO3.13 cells after $24 \mathrm{~h}$ incubation. The apoptotic nature of the cell death was indicated by both the Hoechst (Figure 2b; upper pictures) and the propidium iodide (Figure $2 \mathrm{~b}$; lower pictures) staining. Normal MO3.13 cells are shown in the left section of the figure, whereas the right section shows typical features of apoptotic cells, such as blebbing and accentuated nuclear staining (arrows).

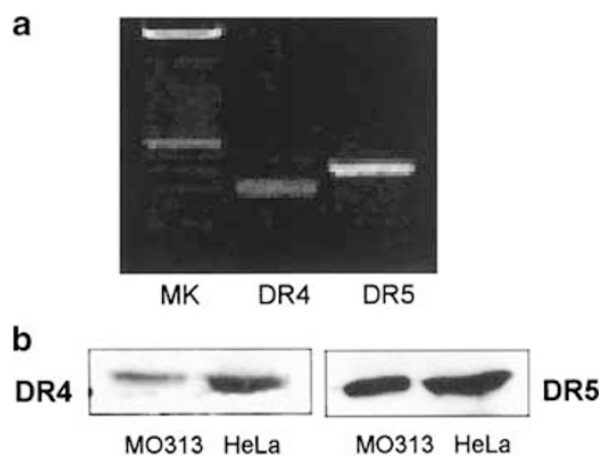

Figure 1 (a) RT-PCR analysis of the two TRAIL DR4 and DR5 receptor mRNAs in the human oligodendrocytic cell line MO3.13. Lane 1: 100 bp laddering (MK); lane 2: DR4; lane 3: DR5. (b) Western blot analysis of the TRAlL receptor DR4 in untreated human oligodendrocytic cells MO3.13 (lane 1); positive control for DR4 was run using HeLa cells (lane 2). (c) Western blot analysis of the TRAIL receptor DR5 in untreated human oligodendrocytic cells MO3.13 (lane 1); positive control for DR5 was run using HeLa cells (lane 2)

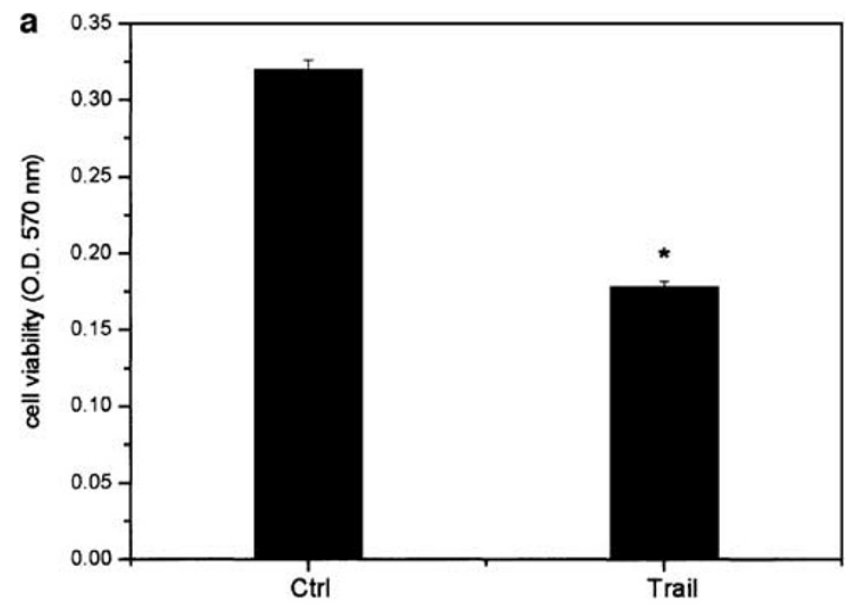

b
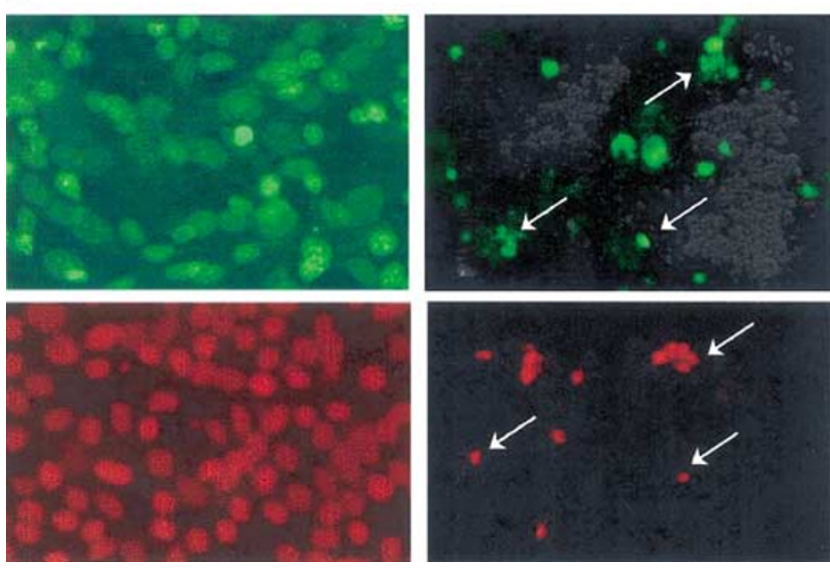

Figure 2 (a) Effects of TRAIL on cell death in the human oligodencrocytic cell line MO3.13. Cells were treated with $100 \mathrm{ng} / \mathrm{ml}$ of the cytokine for $24 \mathrm{~h}$. Vertical bars are mean + S.E. of at least three separate experiments from two separate culture preparations; ${ }^{*} p<0.05$ (Student's $t$-test). (b) Hoechst 33258 (upper section) and propidium iodide (lower section) staining performed upon the human oligodendrocytic cell line MO3.13 untreated (left pictures) or treated with TRAIL ( $100 \mathrm{ng} / \mathrm{ml}$ for $24 \mathrm{~h}$; right pictures). Arrows point to cells showing features of apoptosis 


\section{E-17- $\beta$ protects human oligodendrocytic cells from TRAIL-induced apoptosis}

An additional set of experiments was carried out to evaluate the capacity of estrogens to counteract TRAIL-induced apoptotic cell death in MO3.13. To do so, we first assessed the presence of the two estrogen receptor (ER) ER $\alpha$ and ER $\beta$ mRNAs by RT-PCR analysis. As shown in Figure $3 a$, both transcripts were present in MO3.13 cells. Samples from

a

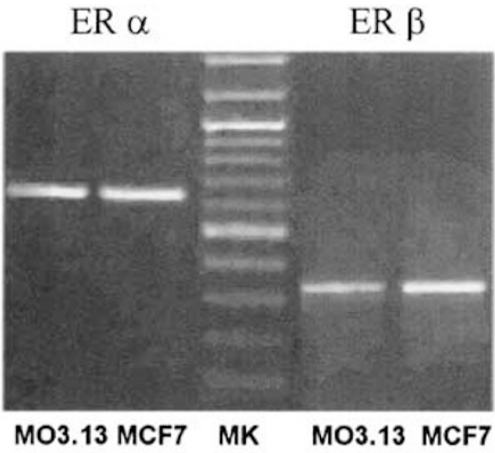

$320 \mathrm{bp}$
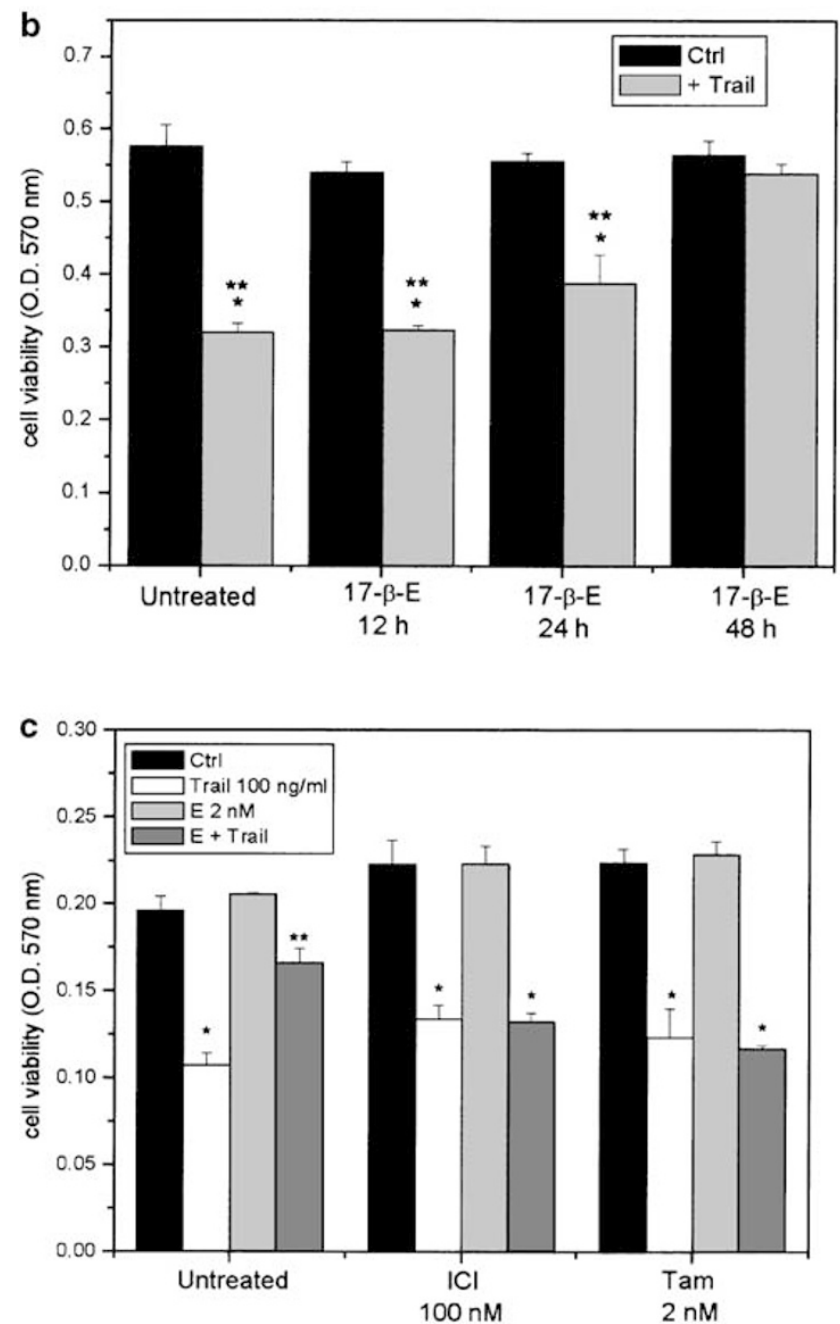

MCF7 cells were used as experimental internal positive controls. $^{30}$

Secondly, we preincubated cells with graded concentrations of E-17- $\beta$ (ranging from 0.2 to $30 \mathrm{nM}$ ) for 12,24 and $48 \mathrm{~h}$ before TRAIL treatment. We found that $\mathrm{E}-17-\beta$ was significantly protected from TRAIL-induced cell death both in concentration- (data not shown) and time-dependent modes. The maximal effect of E-17- $\beta$ occurred at a concentration of $2 \mathrm{nM}$ for a $48 \mathrm{~h}$ incubation (Figure $3 \mathrm{~b}$ ).

The specificity of the protective effects of $\mathrm{E}-17-\beta$ was proven by the ability of the two ER antagonists tamoxifene and $\mathrm{ICI} 187,580(2 \mathrm{nM})$ to restore TRAIL-dependent cell death abrogating the protective effect of estradiol (Figure $3 c$ ) totally. The concentrations of the two ER antagonists used in these experiments were defined by $t$ concentration-response analysis carried out previously (range: $10 \mathrm{pM}-10 \mu \mathrm{M}$; data not shown).

Protective effects of estradiol on TRAIL-induced cell death (Figure 4a) were also confirmed in experiments using specific staining for apoptosis (Figure 4b).

In addition, we attempted to provide evidence that estradiol could affect TRAIL receptor expression. Since we had previously demonstrated modulatory effects of TRAIL on its own receptors in neuronal-like cell line,${ }^{18}$ we first investigated whether receptor expression could be modulated by the addition of the cytokine itself to MO3.13 cultures. Both DR4 and DR5 protein levels were increased by the addition of TRAIL $(100 \mathrm{ng} / \mathrm{ml})$ to the MO3.13 cell cultures after $24 \mathrm{~h}$ incubation (Figure 5).

DR4 and DR5 TRAIL-induced expression was effectively suppressed by treatment with $\mathrm{E}-17-\beta(2 \mathrm{nM})$ in a timedependent manner, reaching maximum inhibition after $48 \mathrm{~h}$ (Figure 5).

Similar effect of estradiol on DR4 and DR5 expression was observed at the mRNA level in Northern blot experiments, suggesting that estrogens act at the transcriptional level (data not shown).

\section{Mechanism of cytotoxic effects of TRAIL: role of caspases and intracellular interactions between estradiol and TRAIL}

It has been suggested that the binding of TRAIL to its deathdomain receptors leads to the activation of caspase-8, with

Figure 3 (a) RT-PCR analysis for the two ER ER $\alpha$ and $\mathrm{ER} \beta$ mRNAs in the human oligodendrocytic cell line MO3.13. Estradiol ER $\alpha$ and $\mathrm{ER} \beta$ receptors in the human oligodendrocytic cell line MO3.13 (respectively lanes 1 and 4) and in an ER-positive strain of the human breast cancer cell line MCF-7 (positive control, respectively, lanes 2 and 5); MK: 100 bp laddering (lane 3). (b) Timedependent effect of E-17- $\beta$ on TRAlL- $(100 \mathrm{ng} / \mathrm{ml})$ induced apoptosis in the human oligodendrocytic cell line MO3.13. Vertical bars are mean + S.E. of at least three separate experiments from two separate culture preparations; ${ }^{*} p<0.05$ (one-way ANOVA, followed by a Duncan test). (c) Abrogation of the protective effect of $2 \mathrm{nM} \mathrm{E-17- \beta}(48 \mathrm{~h}$ ) in the human oligodendrocytic cell line MO3.13 treated for $24 \mathrm{~h}$ with TRAlL $(100 \mathrm{ng} / \mathrm{ml})$ by treatment with the two ER antagonists tamoxifen and $\mathrm{ICI} 187,580(2 \mathrm{nM})$. The drugs were incubated together with or without E-17- $\beta$ for $48 \mathrm{~h}$. Vertical bars are mean + S.E. of at least three separate experiments from two separate culture preparations; ${ }^{*} p<0.05$ (one-way ANOVA, followed by a Duncan test) 


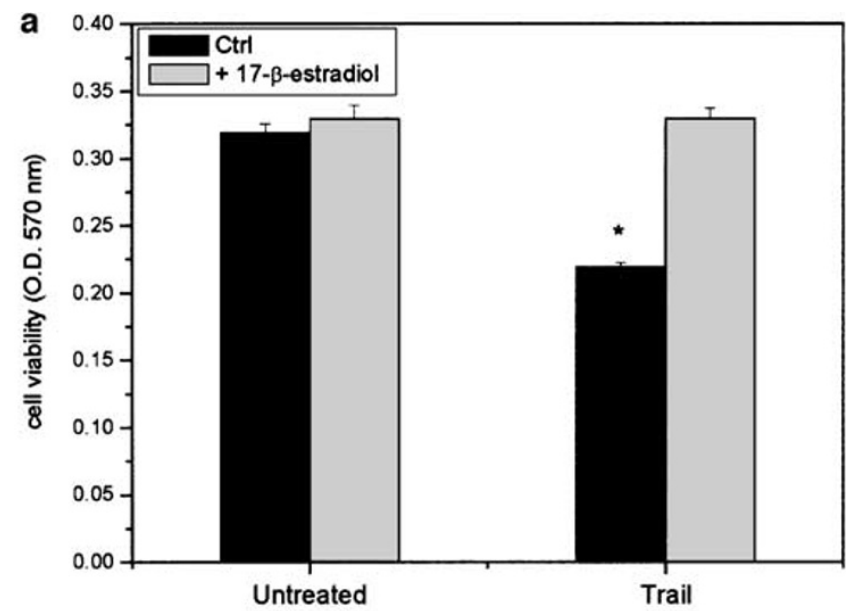

b
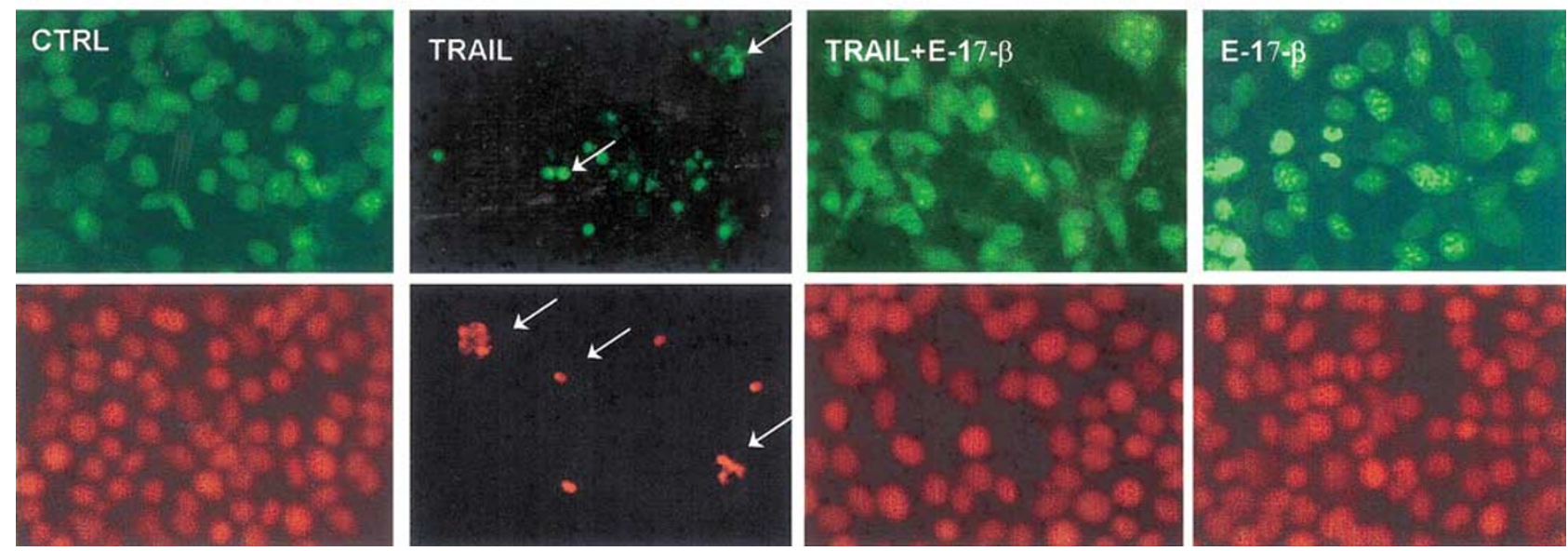

Figure 4 (a) Effect of $48 \mathrm{~h}$ pretreatment with E-17- $\beta(2 \mathrm{nM})$ in the human oligodendrocytic cell line MO3.13, then treated for $24 \mathrm{~h}$ with TRAIL (100 ng/ml). Vertical bars are mean + S.E. of at least three separate experiments from two separate culture preparations; ${ }^{*} p<0.05$ (one-way ANOVA, followed by a Duncan test). (b) Hoechst 33258 (upper section) and propidium iodide (lower section) staining performed upon the human oligodendrocytic cell line MO3.13 treated as indicated. TRAIL: $100 \mathrm{ng} / \mathrm{ml}$ for $24 \mathrm{~h} ; \mathrm{E}-17-\beta: 2 \mathrm{nM}$, added $48 \mathrm{~h}$ prior to TRAIL. Arrows point to cells showing features of apoptosis

\section{DR4}

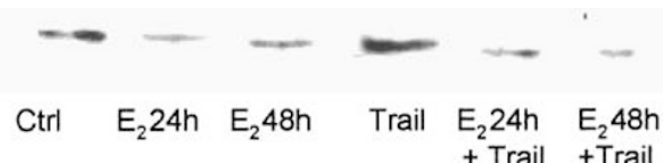

DR5

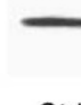

Ctrl
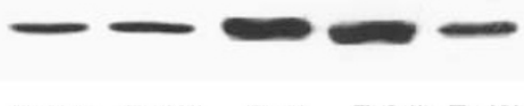

$E_{2} 24 h \quad E_{2} 48 h$ Trail $E_{2} 24 h E_{2} 48 h$

$$
+ \text { Trail +Trail }
$$

\section{$\beta$-tubulin}

Figure 5 Effects of 17- $\beta$-E upon DR4 and DR5 TRAIL receptor and $\beta$-tubulin expression in the human oligodendrocytic cell line MO3.13. Western blot analysis was performed as follows: lane 1 , untreated cells; lane 2 , cells treated $24 \mathrm{~h}$ with $\mathrm{E}-17-\beta(2 \mathrm{nM})$; lane 3 , cells treated $48 \mathrm{~h}$ with $\mathrm{E}-17-\beta(2 \mathrm{nM})$; lane 4 , cells treated $24 \mathrm{~h}$ with TRAIL $(100 \mathrm{ng} / \mathrm{ml})$; lane 5 , cells preincubated $24 \mathrm{~h}$ with $\mathrm{E}-17-\beta$ and then treated with TRAIL for additional $24 \mathrm{~h}$; lane 6 , cells preincubated $48 \mathrm{~h}$ with $\mathrm{E}-17-\beta$ and then treated with TRAIL for additional $24 \mathrm{~h}$. Data represent results from at least two different experiments in different cultures the subsequent activation of caspase- 3 , finally resulting in apoptosis. Caspase-8 activation via TRAIL may occur, in turn, through the recruitment of the adaptor protein FADD. The involvement of FADD in apoptosis of MO3.13 cells was examined by overexpressing FADD or its dominant-negative form (FADD-DN) in these cells. As shown in Figure 6a, overexpression of FADD caused cytotoxic effects leading to about $50 \%$ of cell viability $48 \mathrm{~h}$ after transfection. The extent of cell loss was comparable to that found after the exposure of cells to TRAIL. The cytotoxic effects induced by FADD and TRAIL was not observed in cells overexpressing the FADDDN.

The involvement of caspase- 8 was also investigated by studying cleavage of procaspase-8 by Western blot analysis. We found that TRAIL induced cleavage of caspase- 8 in MO3.13 cells and this effect was completely prevented when cells were preincubated with E-17- $\beta$ for $48 \mathrm{~h}$ (Figure $6 \mathrm{~b}$ ).

To better characterize caspase-8 activation and the subsequent involvement of caspase-3 in MO3.13 cell death induced by TRAIL, cells were preincubated with either the specific caspase-8 inhibitor Z-IETD-FMK $(2 \mu \mathrm{M})$ or the specific 


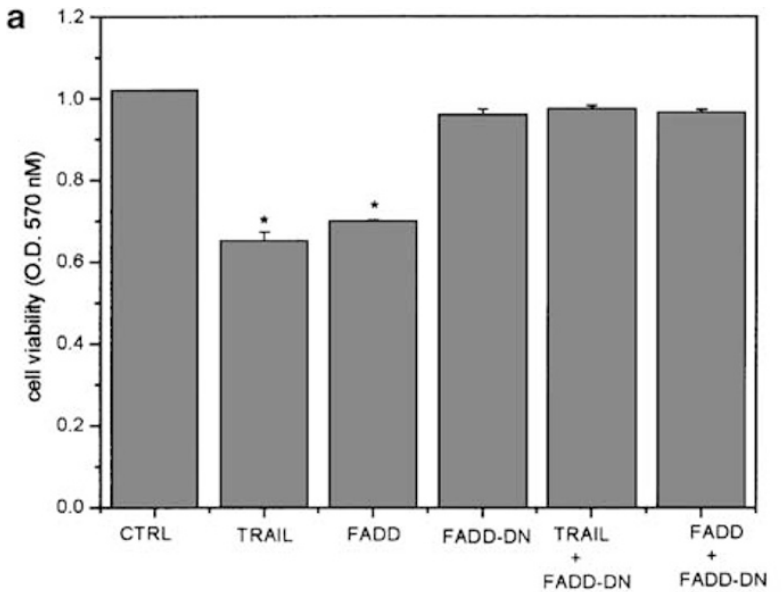

b

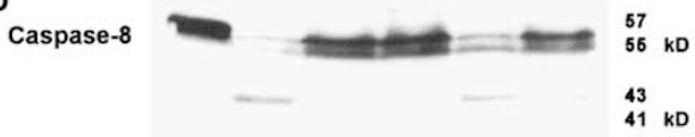

CTRL TRAIL E2 24h E2 48 h E2 24 h E2 48 h $\stackrel{+}{+} \stackrel{+}{+}$

C

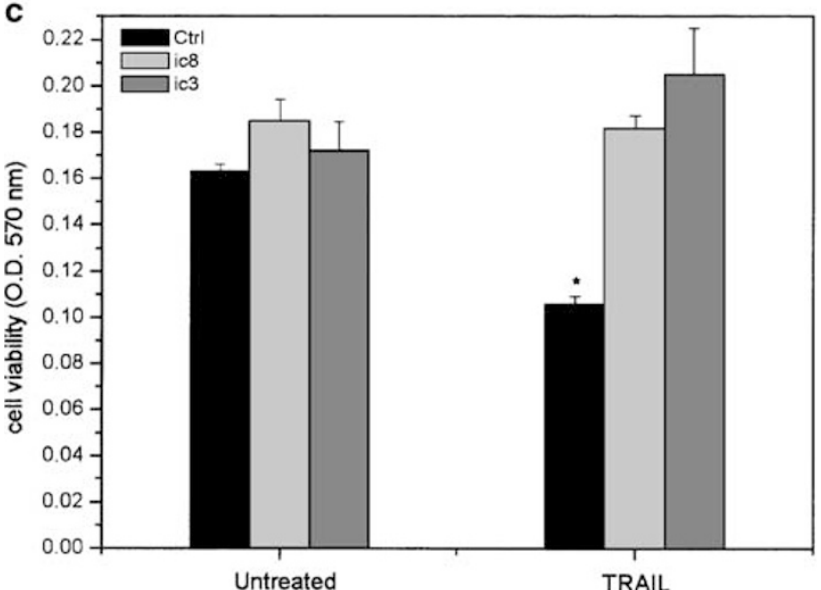

Figure 6 (a) Loss of FADD activity abrogates TRAIL toxicity in the human oligodendrocytic cell line MO3.13. Cells were transfected with plasmid with no insert ( $p c D N A$ ), FADD (pc FADD), or FADD dominant negative (pc FADD DN) and, $48 \mathrm{~h}$ later, incubated, where indicated, for $24 \mathrm{~h}$ with TRAIL. Cell viability was determined by the crystal violet staining. Vertical bars represent the mean \pm S.E. of at least three separate experiments from two separate culture preparations. ${ }^{*} p<0.05$ versus other experimental groups (one-way ANOVA followed by a Duncan test). (b) Inhibitory effects of E-17- $\beta$ on caspase-8 activation in the human oligodendrocytic cell line MO3.13. Western blot analysis was performed as follows: lane 1, untreated cells; lane 2, cells treated $24 \mathrm{~h}$ with TRAIL (100 ng/ $\mathrm{ml})$; lane 3 , cells treated $24 \mathrm{~h}$ with E-17- $\beta(2 \mathrm{nM})$; lane 4 , cells treated $48 \mathrm{~h}$ with $\mathrm{E}$ $17-\beta(2 \mathrm{nM})$; lane 5 , cells preincubated $24 \mathrm{~h}$ with $\mathrm{E}-17-\beta$ and then treated with TRAlL for additional $24 \mathrm{~h}$; lane 6 , cells preincubated $48 \mathrm{~h}$ with E-17- $\beta$ and then treated with TRAIL for additional $24 \mathrm{~h}$. Caspase-8 is identified in its proenzyme and cleaved forms, respectively, $57-55$ and $43-41 \mathrm{kDa}$. (c) Effects of the specific caspase-8 inhibitor Z-IETD-FMK $(2 \mu \mathrm{M})$ or the specific the caspase-3 inhibitor ZDEVD-FMK $(2 \mu \mathrm{M})$ in the human oligodencrocytic cell line MO3.13 exposed to $100 \mathrm{ng} / \mathrm{ml}$ TRAIL for $24 \mathrm{~h}$. Cell viability was determined by the crystal violet staining. Vertical bars represent the mean \pm S.E. of at least three separate experiments from two separate culture preparations. ${ }^{*} p<0.05$ versus control values (one-way ANOVA followed by a Duncan test) a p-JNK-1

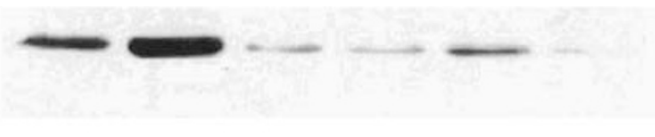

JNK-1

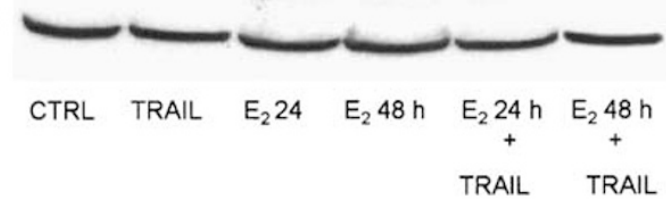

b

Phospho-p38

Total p38

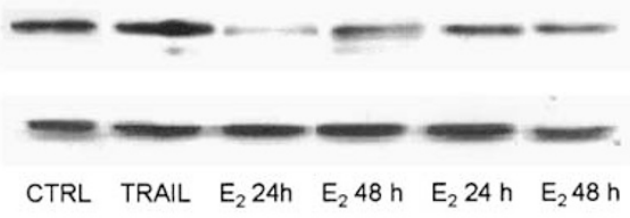

TRAIL TRAIL

Figure 7 (a) Inhibitory effects of $17-\beta$-E on TRAIL-dependent JNK1 phosphorylation in the human oligodendrocytic cell line MO3.13. Western blot analysis was performed as follows: lane 1, untreated cells; lane 2, cells treated $2 \mathrm{~h}$ with TRAIL $(100 \mathrm{ng} / \mathrm{ml})$; lane 3 , cells treated $24 \mathrm{~h}$ with E-17- $\beta(2 \mathrm{nM})$; lane 4 , cells treated $48 \mathrm{~h}$ with E-17- $\beta(2 \mathrm{nM})$; lane 5 , cells preincubated $24 \mathrm{~h}$ with $\mathrm{E}-17-\beta$ and then treated with TRAIL for additional $2 \mathrm{~h}$; lane 6 , cells preincubated $48 \mathrm{~h}$ with $\mathrm{E}-17-\beta$ and then treated with TRAIL for additional $2 \mathrm{~h}$. (b) Inhibitory effects of $\mathrm{E}$ $17-\beta$ on TRAIL-dependent p38 kinase phosphorylation in the human oligodendrocytic cell line MO3.13. Western blot analysis was performed as follows: lane 1, untreated cells; lane 2, cells treated $2 \mathrm{~h}$ with TRAIL $(100 \mathrm{ng} / \mathrm{ml})$; lane 3 , cells treated $24 \mathrm{~h}$ with E-17- $\beta(2 \mathrm{nM})$; lane 4 , cells treated $48 \mathrm{~h}$ with E-17- $\beta$ $(2 \mathrm{nM})$; lane 5 , cells preincubated $24 \mathrm{~h}$ with E-17- $\beta$ and then treated with TRAIL for additional $2 \mathrm{~h}$; lane 6 , cells preincubated $48 \mathrm{~h}$ with $\mathrm{E}-17-\beta$ and then treated with TRAIL for additional $2 \mathrm{~h}$. In both panels, the upper part of the blot represents the phosphorylated form of the protein; the lower part its unphosphorylated form. Data represent results from at least two different experiments in different cultures

caspase-3 inhibitor Z-DEVD-FMK $(2 \mu \mathrm{M})$. Both compounds were able to prevent death of MO3.13 cells incubated $24 \mathrm{~h}$ with TRAIL (Figure 6c).

As it has been shown that TRAIL induces apoptosis through the $\mathrm{JNK} / \mathrm{p} 38$ kinase pathway and that such activation requires cleavage of caspase- $8,{ }^{19,20}$ we investigated the involvement of these kinases in our system.

Indeed, Western blot analysis showed that, whereas basal phosphorylation of JNK1 was significantly increased by TRAIL, it was reduced by E-17- $\beta$ alone. Addition of TRAIL in cultures pretreated with $\mathrm{E}-17-\beta$ for $24 \mathrm{~h}$ partially restored phosphorylation of JNK1, but failed to restore phosphorylation after $48 \mathrm{~h}$ incubation with the estrogen (Figure 7a). A similar pattern was observed for p38 kinase (Figure $7 b$ ).

\section{E-17- $\beta$ prevention of TRAIL-induced apoptosis is associated with an increase in the antiapoptotic genes bcl-2 and $\mathrm{bcl}-\mathrm{xL}$ expression}

Based on reports that $\mathrm{E}-17-\beta$ protects glial cells from apoptotic death by inducing the expression of antiapoptotic proteins of the bcl family, we investigated the role of bcl-2 and bcl-xL expression in MO3.13 cells treated with TRAIL, by Western blot analysis. 


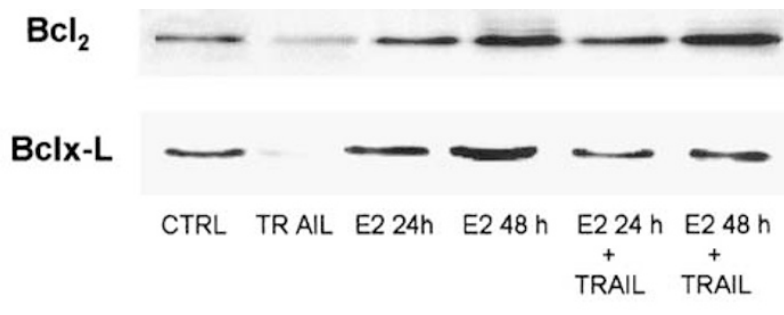

$\beta$-tubulin

Figure 8 Effects of E-17- $\beta$ upon bcl-2 and bclx-L proteins, and $\beta$-tubulin expression in the human oligodendrocytic cell line MO3.13. Western blot analysis was performed as follows: lane 1, untreated cells; lane 2, cells treated $24 \mathrm{~h}$ with TRAIL ( $100 \mathrm{ng} / \mathrm{ml})$; lane 3 , cells treated $24 \mathrm{~h}$ with E-17- $\beta(2 \mathrm{nM})$; lane 4 , cells treated $48 \mathrm{~h}$ with E-17- $\beta(2 \mathrm{nM})$; lane 5 , cells preincubated $24 \mathrm{~h}$ with E-17- $\beta$ and then treated with TRAIL for additional $24 \mathrm{~h}$; lane 6 , cells preincubated $48 \mathrm{~h}$ with $\mathrm{E}$ $17-\beta$ and then treated with TRAIL for additional $24 \mathrm{~h}$. Data represent results from at least two different experiments in different cultures

Both bcl-2 and $b c l-x L$ were found to be expressed at significant levels in untreated cells. Treatment of cells with TRAIL resulted in the downregulation of both bcl-2 and bcl-xL, while treatment with estrogen for 24 or $48 \mathrm{~h}$ resulted in the upregulation of both proteins. When combined, TRAIL was unable to abolish the effect of E-17- $\beta$ (Figure 8).

\section{Discussion}

It has been hypothesized that estradiol may play a neuroprotective role. ${ }^{31,32}$ However, the molecular mechanisms of interaction of female steroids with noxious stimuli remain, so far, largely unclarified. For the first time, in the present paper, we provide evidence for protective effects of estradiol on oligodendrocyte death caused by the powerful proapoptotic cytokine TRAIL.

First, by using different methods, we have shown that TRAIL caused death of the human oligodendrocyte cell line MO3.13, which expresses both functional TRAIL receptors DR4 and DR5, supporting the previously described effects of the cytokine upon primary human oligodendrocytes. ${ }^{28}$ Accordingly, such TRAIL-induced oligodendrocyte death was of apoptotic nature.

Then, in the attempt to characterize the TRAIL death pathway, we found that TRAIL upregulates its receptors in MO3.13 cells. This confirms our previous observation that DR5 receptor expression on human neuronal cell lines exposed to $\beta$-amyloid is upregulated also by TRAIL. ${ }^{18}$ Thus, the subsequent activation of TRAIL surface death receptors DR4 and DR5 may finally trigger an apoptosis program in oligodendrocytic cells. Our data are in accordance with the general concept that cytokines can regulate their own receptors, ${ }^{33-36}$ in either a paracrine or an autocrine manner, and with the observation that oligodendrocytes remain sensitive to TRAIL-induced apoptosis, in conditions where other cells, such as microglia, become insensitive to it. In fact, TRAIL upregulates its own decoy receptors in the latter cell type, thus neutralizing the effects of the molecule. ${ }^{28}$
It is known that, after stimulation by TRAIL, the apoptosistransducing receptors DR4 and DR5 homo- or heterotrimerize and then bind to downstream death-domain proteins, such as FADD, TRADD and RIP, depending upon the cellular system. ${ }^{37,38}$ The recruitment of FADD seems crucial since it allows the activation of caspase- 8 leading in turn to cell death. ${ }^{37,38}$ Our results show that TRAIL activates caspase-8 through FADD and the lack of FADD function in cells transfected with its DN form rescues them from TRAILinduced cell death. We also demonstrated that TRAIL effects are mediated both by caspase- 8 and -3 , since the addition of the respective specific inhibitors of the two enzymes to cultures resulted in the complete suppression of TRAILinduced cell death.

Moreover, as TRAIL-activated caspases also imply the activation of the downstream molecules JNK1 and p38 kinase, we have observed TRAIL-induced phosphorylation of both proteins during an incubation of $1-2 \mathrm{~h}$, a time considered as optimal to observe TRAIL effects. ${ }^{39}$ Finally, the exposure of cells to TRAIL also resulted in the downregulation of two antiapoptotic proteins belonging to the $\mathrm{bcl}$ family, namely bcl-2 and bcl-xL.

Oligodendrocytic MO3.13 cells also expressed both ER subtypes $\alpha$ and $\beta$, thus suggesting that these cells could be responsive to estradiol. In fact, when the steroid was added to the culture media prior to TRAIL, we observed a significant, concentration-dependent decrease in the number of dead oligodendrocyte. Nuclear staining data supported cell viability experiments, suggesting that estradiol prevents TRAILinduced apoptosis of MO3.13 cells. The beneficial effect of estradiol was specific, as the addition to the cultures of the two ER antagonists tamoxifen or $\mathrm{ICl} 187,580$ at concentrations not influencing protein synthesis and known to antagonize estradiol effects in most in vitro systems, ${ }^{40,41}$ resulted in restored cell death rate after addition of TRAIL.

Interestingly, estradiol substantially prevented TRAIL-induced DR4 and DR5 expression. It appears reasonable to hypothesize that protective effects of estradiol could be mediated, at least in part, by its ability to downregulate TRAIL receptor molecules at the transcriptional level.

Interestingly, literature reports that estradiol also inhibits caspase-3 in rat mesencephalic neurons in vitro, ${ }^{42}$ and, in addition, inhibits caspases through a receptor-mediated, nongenomic induction of a specific inhibitor, CIF, in primary human neurons. ${ }^{26}$ In accordance with these data, our present findings show that the treatment of $\mathrm{MO} 3.13$ cells with estradiol resulted in the inhibition of TRAIL-induced caspase-8 activation.

There are controversial hypotheses on the mechanism underlying neuroprotective effects of estradiol, as literature suggests that it might make cells more resistant to injuries, ${ }^{43}$ or rather attenuate toxicity phenomena mediated by nonneuronal cells, ${ }^{44,45}$ including, for example, glial production of proinflammatory cytokines, such as IL-1, TNF- $\alpha^{46}$ and others. In this regard, our data indicated that estrogen treatment per se causes a reduction in the JNK1 and p38 kinase phosphorylation levels and upregulation of $\mathrm{bcl}-2$ and $\mathrm{bcx}-\mathrm{L}$ protein contents, supporting the first theory.

To summarize, we have found that estradiol efficaciously prevents TRAIL-induced oligodendrocytic cell death. Such 
estradiol-dependent inhibition of TRAIL-induced apoptosis appears mediated by (1) direct effects on the cells, including decreased phosphorylation state of the caspase-related JNK1 and p38 kinases and increased levels of the antiapoptotic proteins of the bcl family, and (2) specific action on the intracellular TRAIL death pathway, such as the prevention of TRAIL-induced DR5 expression. These effects may contribute together to generate oligodendrocytes more resistant to different apoptotic stimuli, including TRAIL. Along with the involvement of oligodendrocytes in demyelinating processes, ${ }^{47,48}$ and with the protective properties of estrogens in murine $E A E,{ }^{49,50}$ our findings suggest novel potential targets for estrogen therapy of MS, and provide further rationale for therapeutic intervention.

\section{Materials and Methods}

\section{Cell cultures and reagents}

All materials and media were from Invitrogen Srl, San Giuliano Milanese, Italy, unless otherwise specified. M03.13 cells were a kind gift from Professor Catherine Waters, Division of Neuroscience, University of Manchester, Manchester, UK.

MCF-7, HeLa and MO3.13 cell lines were grown in Dulbecco's modified Eagle's medium (DMEM) supplemented with $10 \%(\mathrm{v} / \mathrm{v})$ fetal calf serum (FCS) and penicillin $(100 \mathrm{U} / \mathrm{ml})$ and streptomycin $(100 \mu \mathrm{g} / \mathrm{ml})$, and kept at $37^{\circ} \mathrm{C}$ in humidified $5 \% \mathrm{CO}_{2}$. MO3.13 were differentiated in DMEM without serum and containing $100 \mathrm{nM} 4$ - $\beta$-phorbol 12 myristate 13-acetate (PMA) for 3 days prior to an experiment as described. ${ }^{51}$

\section{M03.13 viability assay}

A total of $1.5 \times 10^{3}$ cells/well were plated in 96-multiwell plates in DMEM without serum containing $100 \mathrm{nM}$ PMA to be differentiated. After $72 \mathrm{~h}$, differentiated cultures were incubated for $48 \mathrm{~h}$ with $17-\beta-\mathrm{E}(2 \mathrm{nM})$ alone or with tamoxifene $(2 \mathrm{nM})$ (Sigma-Aldrich, St. Louis, MO, USA) or $\mathrm{ICl}$ $182.780(100 \mathrm{nM})$ (Tocris, UK) in phenol red-free DMEM with $1 \%$ FCS. Then, the medium was replaced with fresh medium containing TRAIL $(100 \mathrm{ng} / \mathrm{ml})$ and its potentiator $(1.5 \mu \mathrm{g} / \mathrm{ml}$; potentiator-enhanced TRAlLinduced cell death; Upstate Biotechnology, Lake Placid, NY, USA) and incubated for other $24 \mathrm{~h}$.

In the other experiment, after the differentiation cells were incubated with $100 \mathrm{ng} / \mathrm{ml}$ TRAIL and its potentiator $(1.5 \mu \mathrm{g} / \mathrm{ml})$ either alone or, respectively, with the caspase-8 inhibitor z-IETD-FMK $(2 \mu \mathrm{M}$; Alexis Biochemicals, San Diego, CA, USA), and the caspase-3 inhibitor DEVDFMK ( $2 \mu \mathrm{M}$; Alexis Biochemicals, San Diego, CA, USA) in serum-free DMEM at $37^{\circ} \mathrm{C}$ for $24 \mathrm{~h}$. The caspase inhibitors were added $30 \mathrm{~min}$ before the TRAIL addition.

At the end of the experiments, cells were stained with $0.5 \%$ crystal violet solution for $30 \mathrm{~min}$, washed with bidistilled water and lysed in 10\% acetic acid for $15 \mathrm{~min}$. Optical density was read at $570 \mathrm{~nm}$.

\section{Transfection}

A total of $5 \times 10^{3}$ cells/well were plated in 96-well plates in DMEM without serum containing $100 \mathrm{nM}$ PMA to be differentiated. $24 \mathrm{~h}$ before transfection, the medium was replaced by $10 \%$ FBS DMEM without antibiotics. The expression vectors for pcDNA Fas-associated death domain (FADD) and its dominant negative (pcDNA FADD-DN) were kindly provided by Dr. Marcus Schuchmann (Klinikum der Johannes Gutenberg,
Universitat, Mainz, Germany). The plasmid DNA (300 ng) was diluted in $25 \mu \mathrm{l}$ of serum and antibiotic-free DMEM/well, and $0.5 \mu \mathrm{l}$ of LF2000 reagent were diluted into $25 \mu \mathrm{l} /$ well in the same media in a different tube and incubated for $5 \mathrm{~min}$ at room temperature. The diluted DNA and LF2000 reagent were then combined and incubated at room temperature for $30 \mathrm{~min}$. The resulting complexes were directly added to cultures $(50 \mu \mathrm{l} /$ well) and incubated for $5 \mathrm{~h}$. The transfection medium was then replaced with the growth medium, containing 10\% FBS without antibiotics. Cells were cultured for additional $48 \mathrm{~h}$ before undergoing specific treatments. Cell viability was evaluated by the crystal violet method.

\section{Western blot analysis}

A total of $6 \times 10^{4}$ cells/well were plated in $6 \mathrm{~cm}$ Petri dishes and grown to $50 \%$ confluence in DMEM without serum containing $100 \mathrm{nM}$ PMA as a differentiating agent. ${ }^{51}$ After $72 \mathrm{~h}$, differentiated cells were incubated for 24 or $48 \mathrm{~h}$ with $\mathrm{E}-17-\beta(2 \mathrm{nM})$ in phenol red-free DMEM with $1 \% \mathrm{FCS}$. Then, medium was replaced with fresh medium containing TRAIL $(100 \mathrm{ng} / \mathrm{ml})$ and incubated, respectively, for 2 additional hours, in the JNK/p38 kinase phosphorylation experiments, or 24 additional hours in all other cases.

Cells were harvested in $100 \mu$ l of lysis buffer containing $50 \mathrm{mM}$ Tris, $\mathrm{pH}$ 7.6, $150 \mathrm{mM} \mathrm{NaCl}, 5 \mathrm{mM}$ EDTA, $1 \mathrm{mM}$ phenyl methyl sulfonyl fluoride, $0.5 \mu \mathrm{g} / \mu \mathrm{l}$ leupeptin, $5 \mu \mathrm{g} / \mu \mathrm{l}$ aprotinin and $1 \mu \mathrm{g} / \mathrm{ml}$ pepstatin. The samples were sonicated and centrifuged at $15000 \times g$ for $30 \mathrm{~min}$ at $4^{\circ} \mathrm{C}$. The resulting supernatants were isolated and the protein content determined by a conventional method (BCA protein assay Kit, Pierce, Rockford, IL, USA). Protein extracts (15 $\mu \mathrm{g}$ ) underwent electrophoresis on $12 \%$ SDSPAGE, and were transferred to nitrocellulose membrane (Schleicher and Schuell, Dassel, Germany). Filters were incubated at room temperature overnight with polyclonal anti-DR5, anti-DR4 (Alexis Biochemicals, San Diego, CA, USA), polyclonal anti-JNK-1 and monoclonal pJNK-1, polyclonal anti-p38 (Santa Cruz Biotechnology, Santa Cruz, CA, USA) and polyclonal antiphospho p38 (Promega Italia, Milan, Italy), monoclonal anticaspase-8 (Cell Signaling Technology Inc., USA), monoclonal anti$\mathrm{Bcl}_{2}$ and polyclonal anti-Bcl-xL (Upstate Biotechnology, NY, USA) or antitubulin (Ab3 Neo Markers) antibody in 5\% nonfat dried milk (Sigma). Secondary antibodies (Amersham Italia S.r.l., Milan, Italy) and a chemiluminescence blotting substrate kit (Amersham Italia S.r.I., Milan, Italy) were used for immunodetection.

\section{Evaluation of apoptosis}

A total of $6 \times 10^{4}$ cells were plated onto glass coverslips in $6 \mathrm{~cm}$ Petri dishes and cultured as described above. For quantitation of apoptosis, cells were stained with Hoechst 33258 (Sigma-Aldrich, St. Louis, MO, USA) $)^{52}$ or propidium iodide ${ }^{53}$ (Sigma-Aldrich, St. Louis, MO, USA) and nuclear morphological changes, such as chromatin condensation and fragmentation, were examined under a fluorescent microscope (Leica).

\section{RT-PCR}

Total RNA from cells grown to $80 \%$ confluence was isolated after solubilization in guanidinium thiocyanate by phenol-chloroform extraction and precipitation. ${ }^{54}$ For first-strand cDNA synthesis, $1 \mu \mathrm{g}$ of total RNA was reverse-transcribed using $25 \mu \mathrm{g} / \mathrm{ml}$ oligo(dT) 12-18 $_{18}$ primer in a final volume of $20 \mu \mathrm{l}$, in the presence of $200 \mathrm{U}$ of M-MLV reverse transcriptase (Invitrogen, San Giuliano Milanese, Italy). The reaction was carried out at $37^{\circ} \mathrm{C}$ for $1 \mathrm{~h}$ and heated at $95^{\circ} \mathrm{C}$ for $10 \mathrm{~min}$, and subsequently for $5 \mathrm{~min}$ at $4^{\circ} \mathrm{C}$. PCR was performed in a total volume of $100 \mu \mathrm{l}$, containing $5 \mu \mathrm{l}$ of the cDNA, $5 \mathrm{pmol}$ of each upstream and downstream primer and $1.8-\mathrm{U}$ of 
Taq polymerase (Invitrogen, San Giuliano Milanese, Italy). The cycle program for (a) human DR4 and human DR5 primers consisted of 35 runs of denaturation at $95^{\circ} \mathrm{C}$ for $45 \mathrm{~s}$, annealing at $60^{\circ} \mathrm{C}$ for $1 \mathrm{~min}$ and elongation at $72^{\circ} \mathrm{C}$ for $1 \mathrm{~min}$; (b) human $\mathrm{ER} \alpha$ primers consisted of 35 runs of denaturation at $95^{\circ} \mathrm{C}$ for $1 \mathrm{~min}$, annealing at $55^{\circ} \mathrm{C}$ for $1 \mathrm{~min}$ and elongation at $72^{\circ} \mathrm{C}$ for $1 \mathrm{~min}$; (c) human $\mathrm{ER} \beta$ primers consisted of 30 runs of denaturation at $95^{\circ} \mathrm{C}$ for $1 \mathrm{~min}$, annealing at $58^{\circ} \mathrm{C}$ for $1 \mathrm{~min}$ and elongation at $72^{\circ} \mathrm{C}$ for $1 \mathrm{~min}$. PCR products were analyzed by $1.0 \%$ agarose-gel electrophoresis and visualized with ethidium bromide. The following RNA transcripts were detected via the amplification of the corresponding CDNAs: the human DR4 using a primer pair composed of the sense primer $5^{\prime}$-ACTCGCTGTCCACTTTCGTCTCTGA-3' and the antisense primer $5^{\prime}$-CATCCCCTGGGCCTGCTGCTGTA-3'; the human DR5 using a primer pair composed of the sense primer $5^{\prime}$ GGGAGCCGCTCATGAGGAAGTT- $3^{\prime}$ and the antisense primer $5^{\prime}$ CTGGGTGATGTTGGATGGGAGAGT-3'; the human ER $\alpha$ using the primer set composed of the sense $5^{\prime}$-TACTGCATCAGATCCAAGGG-3' and antisense $5^{\prime}$-ATCAATGGTGCACTGGTTGG-3'; the human ER $\beta$ using the primer pair composed of the sense $5^{\prime}$-GATGAGGGGAAATGCGTAGA- $3^{\prime}$ and the antisense $5^{\prime}$-CTTGTTACTCGCATGCCTGA- $3^{\prime}$; the human GADPH using the primer set composed of the sense $5^{\prime}$ CCACCCATGGCAAATTCCATG-3' and antisense 5'-TCTAGACGGCAGGTCAGGTCCACC-3'.

\section{Northern blot analysis}

A total of $3 \times 10^{6}$ cells/well were plated in $10 \mathrm{~cm}$ Petri dishes and grown to $50 \%$ confluence in DMEM without serum containing $100 \mathrm{nM}$ PMA as a differentiating agent. ${ }^{51}$ After $72 \mathrm{~h}$, differentiated cells were incubated for 24 or $48 \mathrm{~h}$ with $\mathrm{E}-17-\beta(2 \mathrm{nM})$ in phenol red-free DMEM with $1 \% \mathrm{FCS}$. Then, medium was replaced with fresh medium containing TRAIL $(100 \mathrm{ng} / \mathrm{ml})$ and its potentiator $(1.5 \mu \mathrm{g} / \mathrm{ml})$ and incubated for 6 additional hours.

Total RNA from cells grown to $80 \%$ confluence was isolated after solubilization in guanidinium thiocyanate by phenol-chloroform extraction and precipitation. ${ }^{54}$

Northern blot analysis was performed according to standard protocols. Total RNA $(20 \mu \mathrm{g})$ was electrophoresed on a formaldehyde-containing $1.2 \%$ agarose-gel. The RNA was transferred to a nylon membrane for hybridization with ${ }^{32} \mathrm{P}$-labeled cDNA probes. The hybridized RNA was detected by autoradiography.

The cDNA probes of DR4, DR5 receptors and the GADPH were synthesized by RT-PCR as described above. The resulting CDNAs were purified by High Pure PCR product (Boehringer, Mannheim, Germany) according the manufacturer's protocol. Then, the probes were labeled with $\left[{ }^{32} \mathrm{P}\right] \mathrm{dCTP}$ by random primer labeling (Invitrogen s.r.l., San Giuliano Milanese, Italy).

\section{Statistical analysis of results}

Results were analyzed by either one- or two-way analysis of variance (ANOVA), followed by Duncan's least significant difference test. Where appropriate, the Student's $t$-test was applied for in vitro data. A $p$-value $<0.05$ was considered significant.

\section{Acknowledgements}

We wish to thank Mrs. Beatrice Di Bella for her skillful editorial assistance.

\section{References}

1. Colman D, Lubetzki $C$ and Reingold $S$ (2003) Multiple paths towards repair in multiple sclerosis. Trends Neurosci. 26: 59-61

2. Carson MJ (2002) Microglia as liaisons between the immune and central nervous systems: functional implications for multiple sclerosis. Glia 40: 218-231

3. Aboul-Enein F, Rauschka H, Kornek B, Stadelmann C, Stefferl A, Bruck W, Lucchinetti C, Schmidbauer M, Jellinger K and Lassmann H (2003) Preferential loss of myelin-associated glycoprotein reflects hypoxia-like white matter damage in stroke and inflammatory brain diseases. J. Neuropathol. Exp. Neurol. 62: 25-33

4. Cimini A, Bernardo A, Cifone MG, Di Marzio L, Di Loreto S, Cifone G and Di Muzio L (2003) TNFalpha downregulates PPARdelta expression in oligodendrocyte progenitor cells: implications for demyelinating diseases. Glia 41: 3-14

5. Robertson J, Beaulieu JM, Doroudchi MM, Durham HD, Julien JP and Mushynski WE (2001) Apoptotic death of neurons exhibiting peripherin aggregates is mediated by the proinflammatory cytokine tumor necrosis factoralpha. J. Cell Biol. 155: 217-226

6. Satoh $\mathrm{Jl}$ and Kuroda $Y$ (2001) Alpha-synuclein expression is up-regulated in NTera2 cells during neuronal differentiation but unaffected by exposure to cytokines and neurotrophic factors. Parkinsonism Relat. Disord. 8: 7-17

7. Nitsch R, Bechmann I, Deisz RA, Haas D, Lehmann TN, Wendling U and Zipp F (2000) Human brain-cell death induced by tumor-necrosis-factor-related apoptosis-inducing ligand (TRAIL). Lancet 356: 827-828

8. Wosik K, Antel J, Kuhlmann T, Bruck W, Massie B and Nalbantoglu G (2003) Oligodendrocyte injury in multiple sclerosis: a role for p53. J. Neurochem. 85 : 635-644

9. Pan G, O'Rourke K, Chinnaiyan AM, Gentz R, Ebner R, Ni J and Dixit VM (1997a) The receptor for the cytotoxic ligand TRAIL. Science 276: 111-113

10. Walczak H, Degli-Esposti MA, Johnson RS, Smolak PJ, Waugh JY, Boiani N, Timour MS, Gerhart MJ, Schooley KA, Smith CA, Goodwin R and Rauch CT (1997) TRAIL-R2: a novel apoptosis-mediating receptor for TRAIL. EMBO J. 16: $5386-5397$

11. Pan G, Ni J, Wei Y, Yu G, Gentz R and Dixit VM (1997b) An antagonist decoy receptor and a death domain-containing receptor for TRAIL. Science 277: 815-818

12. Sheridan JP, Marsters S, Pitti RM, Gurney A, Skubatch M, Baldwin D, Ramakrishnan L, Gray CL, Baker K, Wood WI, Goddard AD, Godowski P and Ashkenazi A (1997) Control of TRAIL-induced apoptosis by a family of signaling and decoy receptors. Science 277: 818-821

13. Degli-Esposti MA, Dougall WC, Smolak PJ, Waugh JY, Smith CA and Goodwin RG (1997) The novel receptor TRAIL-R4 induces NF-kappaB and protects against TRAIL-mediated apoptosis, yet retains an incomplete death domain. Immunity 7: 813-820

14. Simonet WS, Lacey DL, Dunstan CR, Kelley M, Chang MS, Luthy R, Nguyen $\mathrm{HQ}$, Wooden S, Bennett L, Boone T, Shimamoto G, DeRose M, Elliott R, Colombero A, Tan HL, Trail G, Sullivan J, Davy E, Bucay N, Renshaw-Gegg L, Hughes TM, Hill D, Pattison W, Campbell P, Sanders S, Van G, Tarpley J, Derby P, Lee R and Boyle WJ (1997) Osteoprotegerin: a novel secreted protein involved in the regulation of bone density. Cell 89: 309-319

15. Shipman CM and Croucher PI (2003) Osteoprotegerin is a soluble decoy receptor for tumor necrosis factor-related apoptosis-inducing ligand/Apo2 ligand and can function as a paracrine survival factor for human myeloma cells. Cancer Res. 63: 912-916

16. Dorr J, Bechmann I, Waiczies S, Aktas O, Walczak H, Krammer PH, Nitsch R and Zipp F (2002) Lack of tumor necrosis factor-related apoptosis-inducing ligand but presence of its receptors in the human brain. J. Neurosci. 22: RC209

17. Martin-Villalba A, Herr I, Jeremias I, Hahne M, Brandt R, Vogel J, Schenkel J, Herdegen T and Debatin KM (1999) CD95 ligand (Fas-L/APO-1L) and tumor necrosis factor-related apoptosis-inducing ligand mediate ischemia-induced apoptosis in neurons. J. Neurosci. 19: 3809-3817

18. Cantarella G, Uberti D, Carsana T, Lombardo G, Bernardini R and Memo M (2003) Neutralization of TRAIL death pathway protects human neuronal cell line from beta-amyloid toxicity. Cell Death. Differ. 10: 134-141

19. Schneider P, Thome M, Burns K, Bodmer JL, Hofmann K, Kataoka T, Holler N and Tschopp J (1997) TRAIL receptors 1 (DR4) and 2 (DR5) signal FADDdependent apoptosis and activate NK- $\kappa$ B. Immunity 7: 831-836 
20. Lin Y, Devin A, Cook A, Keane MM, Kelliher M, Lipkowitz S and Liu ZG (2000) The death domain kinase RIP is essential for TRAIL (Apo2L)-induced activation of IkappaB kinase and c-Jun N-terminal kinase. Mol. Cell. Biol. 20: 6638-6645

21. Duquette $P$ and Girard M (1993) Hormonal factors in susceptibility to multiple sclerosis. Curr. Opin. Neurol. Neurosurg. 6: 195-201

22. Santagati S, Melcangi RC, Celotti F, Martini L and Maggi A (1994) Estrogen receptor is expressed in different types of glial cells in culture. J. Neurochem. 63: 2058-2064

23. Confabreux $C$, Hutchinson M, Hourse MM, Cortinovis-Tourniaire $P$ and Moreau T (1998) Rate of pregnancy-related relapse in multiple sclerosis. N. Engl. J. Med. 339: 285-291

24. Bebo Jr BF, Schuster JC, Vandenbark AA and Offner H (1999) Androgens alter the cytokine profile and reduce encephalitogenicity of myelin reactive T cells. J. Immunol. 162: 35-40

25. Voskuhl RR, Pitchekian-Halabi H, MacKenzie-Graham A, McFarland HF and Raine CS (1996) Gender differences in autoimmune demyelination in the mouse: implications for multiple sclerosis. Ann. Neurol. 39: 724-733

26. Zhang Y, Tounekti O, Akerman B, Goodyer CG and LeBlanc A (2001) 17- $\beta$ estradiol induces an inhibitor of active caspases. J. Neurosci. 21: 1-6

27. Lee MW, Park SC, Yang YG, Yim SO, Chae HS, Bach JH, Lee HJ, Kim KY, Lee WB and Kim SS (2002) The involvement of reactive oxygen species (ROS) and p38 mitogen-activated protein (MAP) kinase in TRAIL/Apo2L-induced apoptosis. FEBS Lett. 512: 313-318

28. Matysiak M, Jurewicz A, Jaskolski D and Selmaj K (2002) TRAIL induces death of human oligodendrocytes isolated from adult brain. Brain 125: 2469-2480

29. McLaurin J, Trudel GC, Shaw IT, Antel JP and Cashman NR (1995) A human glial hybrid cell line differentially expressing genes subserving oligodendrocyte and astrocyte phenotype. J. Neurobiol. 26: 283-293

30. Haczynski J, Tarkowski R, Jarzabek K, Slomczynska M, Wolczynski S Magoffin DA, Jakowicki JA and Jakimiuk AJ (2002) Human cultured skin fibroblasts express estrogen receptor alpha and beta. Int. J. Mol. Med. 10: $149-153$

31. Green PS and Simpkins JW (2000) Neuroprotective effects of estrogens: potential mechanisms of action. Int. J. Dev. Neurosci. 18: 347-358

32. Lee SJ and McEwen BS (2001) Neurotrophic and neuroprotective actions of estrogens and their therapeutic implications. Annu. Rev. Pharmacol. Toxicol. 41: $569-591$

33. Smolnikar K, Loffek S, Schulz T, Michna H and Diel P (2000) Treatment with the pure antiestrogen faslodex $(\mathrm{ICl} 182780)$ induces tumor necrosis factor receptor 1 (TNFR1) expression in MCF-7 breast cancer cells. Breast Cance Res. Treat. 63: 249-259

34. Sunyer T, Lewis J, Collin-Osdoby P and Osdoby P (1999) Estrogen's boneprotective effects may involve differential IL-1 receptor regulation in human osteoclast-like cells. J. Clin. Invest. 103: 1409-1418

35. Deb S, Tessier C, Prigent-Tessier A, Barkai U, Ferguson-Gottschall S, Srivastava RK, Faliszek J and Gibori G (1999) The expression of interleukin-6 (IL-6), IL-6 receptor, and gp130-kilodalton glycoprotein in the rat decidua and a decidual cell line: regulation by 17 beta-estradiol and prolactin. Endocrinology 140: 4442-4450

36. LaVallee TM, Zhan XH, Johnson MS, Herbstritt CJ, Swartz G, Williams MS Hembrough WA, Green SJ and Pribluda VS (2003) 2-methoxyestradiol upregulates death receptor 5 and induces apoptosis through activation of the extrinsic pathway. Cancer Res. 63: 468-475

37. Sprick MR, Weigand MA, Rieser E, Rauch CT, Juo P, Blenis J, Krammer PH and Walczak H (2000) FADD/MORT1 and caspase-8 are recruited to TRAIL receptors 1 and 2 and are essential for apoptosis mediated by TRAIL receptor 2. Immunity 12: 599-609

38. Kischkel FC, Lawrence DA, Chuntharapai A, Schow P, Kim KJ and Ashkenazi A (2000) Apo2L/TRAIL-dependent recruitment of endogenous FADD and caspase-8 to death receptors 4 and 5. Immunity 12: 611-620

39. Pawlowski JE, Nesterov A, Scheinman RI, Johnson TR and Kraft AS (2000) NF-kappa B does not modulate sensitivity of renal carcinoma cells to TNF alpha-related apoptosis-inducing ligand (TRAIL). Anticancer Res. 20: 4243-4255

40. Kim H, Bang OY, Jung MW, Ha SD, Hong HS, Huh K, Kim SU and Mook-Jung I (2000) Neuroprotective effects of estrogen against beta-amyloid toxicity are mediated by estrogen receptors in cultured neuronal cells. Neurosci. Lett. 302 : $58-62$

41. Kauser K, Sonnenberg D, Diel P and Rubanyi GM (1998) Effect of 17betaoestradiol on cytokine-induced nitric oxide production in rat isolated aorta. Br. J. Pharmacol. 123: 1089-1096

42. Sawada H, Ibi M, Kihara T, Urushitani M, Honda K, Nakanishi M, Akaike A and Shimohama S (2000) Mechanisms of antiapoptotic effects of estrogens in nigral dopaminergic neurons. FASEB J. 14: 1202-1214

43. Wise PM, Dubal DB, Wilson ME and Rau SW (2000) Estradiol is a neuroprotective factor in in vivo and in vitro models of brain injury. J. Neurocytol. 29: 401-410

44. Dhandapani KM and Brann DW (2002) Estrogen-astrocyte interactions: implications for neuroprotection. BMC Neurosci. 3: 6

45. Garcia-Segura LM, Naftolin F, Hutchison JB, Azcoitia I and Chowen JA (1999) Role of astroglia in estrogen regulation of synaptic plasticity and brain repair. J. Neurobiol. 40: 574-584

46. Burger D and Dayer JM (2002) Cytokines, acute-phase proteins, and hormones: IL-1 and TNF-alpha production in contact-mediated activation of monocytes by T lymphocytes. Ann. N Y Acad. Sci. 966: 464-473

47. Cimini A, Bernardo A, Cifone MG, Di Marzio L, Di Loreto S, Cifone G and Di Muzio L (2003) TNFalpha downregulates PPARdelta expression in oligodendrocyte progenitor cells: implications for demyelinating diseases. Glia 41: 3-14

48. Scarisbrick IA, Blaber SI, Lucchinetti CF, Genain CP, Blaber M and Rodriguez M (2002) Activity of a newly identified serine protease in CNS demyelination. Brain 125: 1283-1296

49. Liu HY, Buenafe AC, Matejuk A, Ito A, Zamora A, Dwyer J, Vandenbark AA and Offner $\mathrm{H}$ (2002) Estrogen inhibition of EAE involves effects on dendritic cell function. J. Neurosci. Res. 70: 238-248

50. Matejuk A, Dwyer J, Zamora A, Vandenbark AA and Offner H (2002) Evaluation of the effects of 17beta-estradiol (17beta-e2) on gene expression in experimental autoimmune encephalomyelitis using DNA microarray. Endocrinology 143: 313-319

51. Craighead MW, Tiwari P, Keynes RG and Waters CM (1999) Human oligodendroglial cell line, MO3.13, can be protected from apoptosis using the general caspase inhibitor zVAD-FMK. J. Neurosci. Res. 57: 236-243

52. Darzynkiewicz Z, Li X and Gong J (1994) Assays of cell viability: discrimination of cells dying by apoptosis. Methods Cell Biol. 41: 15-38

53. Jones KH and Kniss DA (1987) Propidium iodide as a nuclear counterstain for immunofluorescence studies on cells in culture. J. Histochem. Cytochem. 35: 123-125

54. Chomczynski P and Sacchi N (1987) Single-step method of RNA isolation by acid guanidinium thiocyanate-phenol-chloroform extraction. Anal. Biochem. 162: $156-159$ 